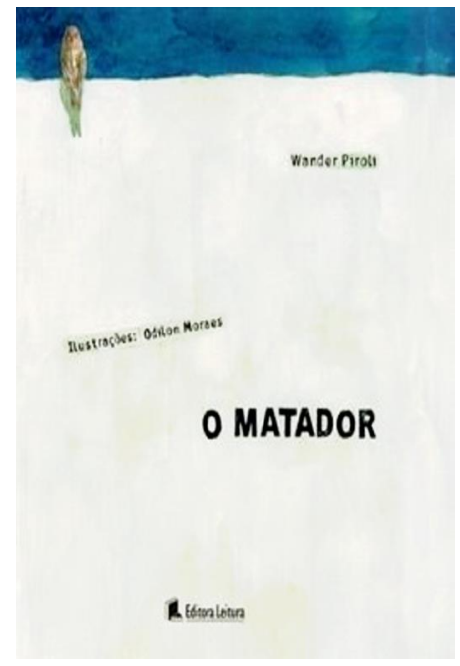

Capa do livro

\title{
O matador
}

\section{Gerlane Roberto de Oliveira}

Mestranda no Programa de Pós-graduação em Estudos Literários na FALE/UFMG com pesquisa sobre literatura infanto-juvenil, especificamente sobre a obra de Lygia Bojunga Nunes.

PIROLI, Wander. O matador. Belo Horizonte: Editora Leitura, 2008. $31 \mathrm{p}$.

Como escrever sobre assuntos delicados como o amor à vida animal, sem pretender dogmatizar as crianças? Como colocar frente ao leitor um texto que ultrapasse o caráter de manual ecológico e o leve a uma reflexão filosófica sobre a própria existência? Essa é uma habilidade desenvolvida por poucos autores ao escreverem para crianças. Entre esses, Wander Piroli (1931-1996) sobressai-se como um dos que acerta o alvo, na escrita de temas da realidade com criatividade linguística, emoção e denúncia daquilo que agride a vida, sem pretensão alguma de dar conselhos para o leitor.

Precursor na temática ecológica para crianças, o autor belohorizontino nos apresenta, em o matador, uma trama que envolve um menino que não tinha um talento fundamental nas brincadeiras da infância: não era habilidoso em matar pássaros, como os outros garotos. Seu percurso de desvantagem em relação às outras crianças começava quando a turma do 
bairro se reunia para fazer pontaria nos pardais. Todos eram bons de bodoque e acertavam sempre o alvo. Ao garoto, restava apenas a angústia e a humilhação dos demais, já que nunca conseguia acertar um pássaro. Porém, suas tentativas continuavam e, por mais que os pássaros até fossem pacíficos, ele não acertava nenhum.

Certo dia, de surpresa, um pardal pousou levemente na cobertura de sua casa. O garoto fez barulho, tentou espantálo, fingiu arremessar uma pedra e o pássaro pacificamente não se moveu. Descontente com sua situação de inábil matador, pegou o bodoque e mirou o alvo, acertando em cheio o pardal, que caiu agonizando. Sua primeira atitude foi correr em direção à rua, para ver se todos os olhares estavam direcionados a seu grande feito. Mas não havia ninguém olhando. Decepcionou-se. E, ao se deparar com o pássaro agonizando em sua mão, viu que o pardal tinha morrido, pois não piava mais. Só lhe restou a lembrança do passarinho:

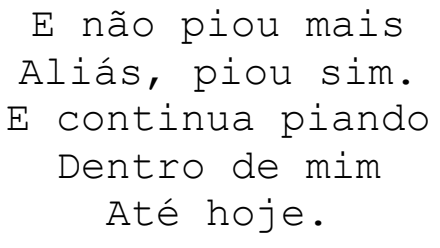

Narrado em primeira pessoa, com uma linguagem enxuta, simples, - conto levanta reflexões sobre as consequências de nossos erros e sentimentos mesquinhos perante aquilo que se mostra superior à condição humana. Como os outros personagens de Piroli, o menino-narrador do conto, também pertence a um ambiente em que todos - animais e homens - lutam pela sobrevivência, mesmo que a condição social e as desgraças não os motivem para isso. Assim, apesar da crueza da ação humana, - sentimento de credibilidade na vida e na sensibilidade ainda persiste.

As ilustrações de odilon Moraes ocupam todas as páginas do livro, servindo de fundo ao texto, que aparece sob a forma de frases de jornal recortadas, dando a ideia de serem uma notícia de crime, das páginas policiais. Mas os desenhos apresentam a leveza das imagens com pinceladas na predominância da cor verde em várias tonalidades, exceto em um detalhe: a mancha vermelha do pássaro morto no coração do menino, o que denuncia o crime humano.

Mesmo não sendo tão lembrado pela crítica literária, Wander Piroli foi vencedor do prêmio Jabuti em 1977, com sua obra mais conhecida, os rios morrem de sede, que já possui mais de trinta edições. Atuou como advogado e jornalista em Belo Horizonte, tendo escrito $A$ mãe e o filho da mãe, Minha bela putana, Eles estão aí fora e Para pegar bagre de dia, é 
preciso sujar a água, dentre outros contos. Sua literatura tem como cenário os espaços periféricos e os subumanos das grandes cidades, povoados de personagens marginalizados em busca de si mesmos na crueza do cotidiano.

Com O matador, Piroli acerta um alvo específico: uma leitura em que as fronteiras entre realidade e ficção são fluidas, sem fechar as possibilidades de leitura de uma obra que pode ser apreciada tanto por crianças como por adultos. Diferentemente de seu personagem inábil em matar pássaros, o autor é perfeitamente habilidoso em acertar leitores que não buscam manuais prontos de sobrevivência e não se contentam com enredos previsíveis. O leitor crítico está na mira de Piroli. E não é que ele acertou?! 